Efektor, Vol. 7. No.1 Tahun 2020, Pages 59-72

Available online at:http://ojs.unpkediri.ac.id/index.php/efektor-e

DOI: https://doi.org/10.29407/e.v7i1.14414

\title{
Green Accounting and Its Implementation in Indonesia
}

\author{
Andi Arjuni K. ${ }^{1}$, Alimuddin' ${ }^{2}$, Hamid Habbe ${ }^{3}$, Mediaty4, Andi Maulana $\mathrm{K}^{5}$ \\ andiarjunipetta@gmail.com¹, alimuddin.febuh@gmail.com², hamidhabbe@gmail.com³, \\ unhasmediaty@gmail.com ${ }^{4}$, andimaulanakamri@gmail.com ${ }^{5}$ \\ Faculty of Economic and Business of Postgraduate Program, Universitas Hasanuddin 1,2,3,4 \\ Faculty of Pharmacy, Universitas Muslim Indonesia ${ }^{5}$
}

\begin{abstract}
The growth of industrial world is an undeniable problem in the environment where industrial behavior often ignores impacts on the environment, such as water, soil, air pollution and social inequality in the environment. The purpose of this study is intended to determine the role of green accounting in reducing environmental pollution and to examine the extent to which the application of green accounting in Indonesia in supporting sustainability. This study uses an interpretive approach which focus on the subjective nature of social world and tries to understand it. Green accounting has difficulty measuring the value of costs and benefits of externalities arising from industrial processes. It is not easy to measure the loss to people around and the ecological environment caused by air pollution, liquid waste, ammonia tube leakage, nuclear tube leakage or other externalities. Unfortunately, in its application, often some companies do not report bad news they are facing, so reporting on environmental costs is not effective.
\end{abstract}

Keywords: green accounting, implementation, environmental costs

\begin{abstract}
Abstrak
Pertumbuhan dunia industry merupakan suatu masalah yang tidak dapat disangkal pada lingkungan dimana perilaku industri sering mengabaikan dampak pada lingkungan, seperti pencemaran air, tanah, udara, dan kesenjangan sosial pada lingkungan. Tujuan dari penelitian ini dimaksudkan untuk mengetahui peran green accounting dalam mengurangi pencemaran lingkungan dan untuk mengkaji sejauh mana penerapan green accounting di Indonesia dalam mendukung keberlangsungaan usaha perusahaan. Penelitian ini menggunakan pendekatan interpretif yang memfokuskan pada sifat subjektif dari social world dan berusaha memahaminya. Green accounting mengalami kesulitan dalam mengukur nilai biata dan manfaat eksternalitas yang timbul dari proses industry. Tidak mudah untuk mengukur kerugian yang diterima orang-orang di sekitar dan lingkungan ekologis yang disebabkan oleh polusi udara, limbah cair, kebocoran tabung ammonia, kebocoran tabung nuklir, atau ekternalitas lainnya. Namun sayangnya, dalam penerapannya, seringkali beberapa perusahaan tidak melaporkan akan berita buruk yang dihadapi, sehingga pelaporan mengenai baya lingkungannya tidak efektif.
\end{abstract}

Keywords: green accounting, penerapan, biaya lingkungan

\section{INTRODUCTION}

The growth of the industrial world is an undeniable problem in the environment where industrial behavior often ignores impacts on the environment, such as water pollution, soil, air and social inequality. As a consequent of the growth of the industrial world, the demands of companies in protecting the environment are even bigger. The company is not only concerned with management and capital owners, but also employees, consumers, and the community. Bebbington (2001) stated that accounting plays an important role in managing relations between company and the environment. From an accounting point of view, social responsibility and responsibility 
environmental responsibility is a unique responsibility, especially related to disclosure and reporting (Riduwan and Andayani, 2011). Environmental responsibility has various influences on company performance. A good company certainly does not only pursue economic profits but also cares about the preservation of the environment and the welfare of the surrounding community. Cooper (1992) said that accounting must play a role to contribute to environmental problems rather than just preventing. The implementation of environmental accounting is aimed at to produce information related to the environment (Burhany, 2014).

Development always causes changes to the environment. It is undeniable that the existence of such development will certainly have an impact on the environment, starting from processing waste bins as a result of development itself (in this case the damage caused by nature changes) to the pollution of the surrounding environment. The environment is polluted either directly or indirectly cause environmental damage. Damage to nature made imbalance and uselessness of the environment, so that lives of humans and living things others are disturbed. Natural disasters that come and go with each other accompany increasingly damage to nature and it is not anyone's fault, but human actions themselves such as floods that occur due to illegal logging and littering. Companies are also sued for contribute to environmental resources used as accountability for stakeholders in the interest of their business.

Entering the 21st century that continues to experience progress and prosperity, the emphasis is given more and more to nature and the environment that surrounds us. However, realizing how important the environment plays a role in our survival and be careful about damage and the impact has to face to the world in the long run, more and more organizations lead, governments and associations realize not only need to protect the environment but also need to create awareness among the community about the importance of the environment. Corporation and Businesses together understand and formulate steps to promote friendliness environment and green for the present and the future. Among the various other steps that are being taken in this case is a new branch of accounting called "Environmental accounting or Green Accounting ". This is also called resource accounting or integrated accounting.

If we reflect on the framework Green Accounting which offered by Greenham (2010) where he proposes a methodology which is categorized into three dimensions, as illustrated in Figure 1, which consists of:

1. WHO - Whose actions are we accounting for?

2. WHEN - When have actions and impacts taken place?

3. WHAT - How are we trying to measure these impacts?

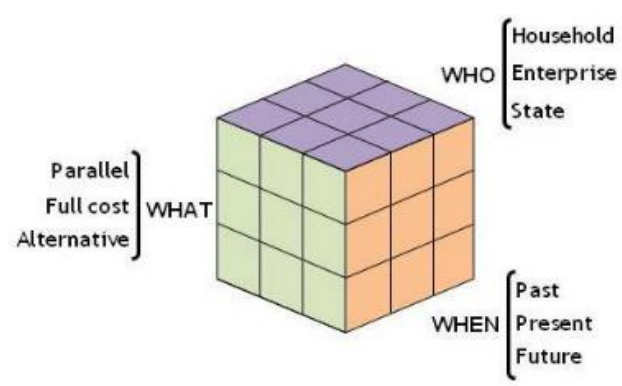

Figure 1. Framework Green Accounting (Greenham, 2010) 
Combining social and environmental considerations might work better at several levels (ex. national accounting, rather than others, such as corporate accounting). However, this framework might be better seen as a step on the way to a comprehensive Green Accounting framework rather than as an end goal.

Accounting as calculate science also implements or includes the environment in implementation of their knowledge. The concept of environmental accounting began to develop in the 1970s in Europe. In Indonesia itself, as a developing country, is inseparable from its environmental problems the more the impact the more is felt. This concept is based on pressure from institutions not the government and it makes people aware of environmental awareness in order companies implementing environmental management are not just industrial activities preferred (Ikhsan, 2008). According to Lodhia (2008), environmental issues have been get attention in recent years through information about the potentially dangerous environment of the activity industry. The biggest event is environmental damage that needs attention and control on commercial activity to encourage sustainable business practices. Likewise, crisis Global ecology that occurs today is a global moral crisis. Therefore, it needed ethics and morality to overcome them. It is undeniable that various environmental cases happening right now, both on a global and national scaled, most of them is sourced from human behavior. Cases of pollution and damage, such as in the sea, forests, atmosphere, water, land, and so on stem from irresponsible, uncaring, and just human behavior selfish. (Kerap, 2006)

Many environmental issues that occur in the wider community such as global warming that occurred in Indonesia. Environmental issues are directly and indirectly included in economic performance a business/ activity or organization. Improving business environment policies and earnings information (profits) for investors and business man based on product environmental protection is one of example that can be presented at this time. Furthermore Ikhsan (2008) said that the primacy of the use of environmental accounting concepts for companies is the ability to minimize the environmental problems they faced. The aim is to improve efficiency of environmental management by evaluating environmental activities from the point of view of costs (environmental cost) and benefits (economic benefits).

In the era of the company's movement towards a green company, industry was not only demanded to treat the waste solely, but the demands of the consumer community are furthermore to make the process production of an item, starting from taking raw materials to disposing of a product after consumption does not damage the environment. This is reinforced by the presence of ISO that contains the criteria environment in the standard production of goods (Idris, 2012).

Seeing the increasingly broad scope of the company that starts from mapping, exploration, exploitation of energy and mineral resources as well as research on minerals, processing of mining products and possible until the use of raw materials in the manufacture of fertilizers and concrete results disturbance to the environment, it is necessary to pay attention and control of pollution environment and ecosystem changes so that sectors which are vital for this development can be preserved. Efforts to manage the environment by referring to the principle of environmentally friendly are needed by companies, for this limited research to see how the implementation of accounting the environment in Indonesia (this will be discussed in section IV). Based on the description above, then 
the problem in this research is how the role of Green Accounting in Indonesia in reducing environmental pollution and implementing Green Accounting in support business continuity of the company. The purpose of this study is intended to determine the role green accounting in reducing environmental pollution and to assess the extent of implementation green accounting in Indonesia in supporting the company's business sustainability.

\section{LITERATURE REVIEW}

The theory of legitimacy has been extensively used to explain motivation of disclosure the environment voluntarily by the organization. As for Asforth and Gibbs, legitimacy can be said as potential benefits or potential sources for companies to survive (Abdullah, 2015). Theory of legitimacy explains that the disclosure of social responsibility is done by the company in its efforts to gain legitimacy from the community where the company is located and maximize its financial strength in the long run. According to Ahmad and Sulaiman (2004) the theory of legitimacy is based on the notion of social contract that is implied between social institutions and public. The legitimacy theory also explained that the practice of corporate responsibility disclosure must be carried out in such a way that the company's activities and performance can be accepted by the community. Ghozali and Chariri (2007) explained that in order to legitimize the activities of companies in the eyes of society, companies tend to use environmental and performance based disclosure of environmental information. The assumption of legitimacy has a relationship of authoritative characteristics, law, feeling, binding or truth attached to a government or order the state is considered legal, if it has rights to govern (Ikbal, 2012).

In the book "Kearifan Lingkungan dalam Praktik Akuntansi" written by Said (2020) it is said that legitimacy is achieved by demonstrating, appropriate organizational activity with social value. In the environmental context, there are two dimensions regarding achievement legitimacy: (1) action (action) in other words is the activity of the organization in accordance with social values and (2) presentation presents the activities that show conformity with social values (Dowling and Pfeffer, 1975). Furthermore Dowling and Pfeffer (1975) explained that the theory of legitimacy in analyzing organizational behavior. They said in paragraph 131: "Because legitimacy is important to the organization, the boundaries are emphasized by social norms and values, and reaction to these limits encourages the importance of analyzing organizational behavior by paying attention environment".

One of reason why this become as basic theory is because entities are part from the community where the activities carried out must be based on norms or rules applies to the surrounding community. Legitimacy theory is very suitable for use in accounting environment like green accounting itself. Because of the legitimacy of that company care for the environment is important so that companies are responsible not only for social but also the environment where the company is located and can continue to be sustainable in the future.

\section{History and Development of Green Accounting}

The term environmental accounting was used for the first time in the 1980s by Professor Peter Wood. The concept of environmental accounting began to develop since the 1970s Europe In the 1990s the International Accounting Standards Committee (IASC) develops concepts about accounting principles internationally, including the development of environmental accounting and human rights audits. In addition, industry standards are also 
growing and professional auditors such as The American Institute of Certified Public Auditors (AICPA) issues universal principles about environmental audits. Background on the importance of accounting the environment basically requires full awareness of companies and organizations others who have benefited from the environment. In Europe, this concept has begun to develop since the 1970s srating with Norway affected by the publications of Limits to Growth (Meadows et al., 1972) and the growing environmental movement. Then this environmental issue also received the attention of the Danish government as result of the oil crisis of 1977 which began to make calculation of energy reserves and savings. In the 1980s, France develops an accounting system for assessing both quantitative and qualitative situations and changes over their natural resources (Vanoli, 2005).

The Environmental Agency of Japanese which changed became the Ministry of Environment issued a guide environmental accounting guidelines in May 2000. This manual was further refined in 2002 and 2005. All companies in Japan are required to implement environmental accounting. Large Japanese companies began to put the position of environmental accounting equal financial accounting. Some reasons why companies need to consider adopting environmental accounting as part of the company's accounting system, including: makes it possible to reduce and eliminate environmental costs, improve performance the company's environment which so far may have a negative impact on human health and business success of the company, are expected to generate costs or more accurate prices on the desired products and environmental processes and enables meeting the needs of customers who expect environmental products/services more friendly.

\section{Definition of Green Accounting (Environmental Accounting)}

According to Arfan Ikhsan in the book Manajemen Akuntansi Lingkungan (2008), environmental accounting is the identification, measurement and allocation of environmental costs and integrating costs into business decision making and communicating the results to the company's stakeholders. Environmental accounting or Green Accounting is a term related to the inclusion of environmental costs into accounting practices of companies or government institutions. Cost environment is the impact, both monetary and non-monetary to be borne as a result of activities that affect environmental quality. According to Prof. Andreas Lako, Professor of Accounting for Sustainability of Unika Soegijapranata, Green Accounting is a new paradigm in accounting that advocates to focus of the accounting process not only on transactions. Financial transactions for produce financial statements can be known profit/loss (profit) corporate entities, but also on transactions/events (social), (people), and the environment (the planet) so that it is well known Information on Social and Environmental Accounting. Green Accounting requires accounting not only focusing on profit but also on humans and the planet.

Green accounting is often grouped into social accounting. It happened because both discourses (environmental accounting and social accounting) have a same purpose, namely internalizing externalities (externalities in the social and environmental environment ecological) both positive and negative, into the company's financial statements. Similar to social accounting environmental accounting also encountered difficulties in measuring the cost and value externality beneficiaries arising from the industry. It is not an easy thing to measure losses which received by the surrounding community and the ecological environment caused air pollution and liquid waste or other externalities from the company. According to Hadjoh (2013) environmental disclosure is very 
beneficial for environmental recovery affect the welfare of humanity and other living things. Green Accounting is also interpreted as an identification, prioritization, quantification, or qualification and incorporation of environmental costs into business decisions (Aniela, 2012). This is parallel with what was expressed by Astuti (2012) that this Green Accounting collect costs, production, inventory, and waste and performance costs for planning, development, evaluation, and control of business decisions. Based on these, then green accounting is the first step that becomes a solution in environmental problems.

Based on the nature of the environmental management system, then by borrowing the definition from Gray and Bebbington (Lako, 2011), the area of environmental accounting includes 1) company contingent risks or liabilities, 2) asset revaluation and capital projections, 3) cost analysis in important areas such as energy, waste and environmental protection, 4) investment interpretation that considers environmental factors, 5) system development new information and accounting systems that cover all environmental performance, 6) assessment on the costs and benefits of environmental improvement programs, 7) technical development accounting techniques for disclosing assets, liabilities and costs and terminology ecological and non-financial. The importance of using environmental accounting for this company is listed in the function and the role of environmental accounting, which is divided into two parts, namely (1) internal functions, is a function that is assembled with the internal company itself. Internal parties are those who run businesses, such as consumer households and production houses and other services (Ikhsan, 2008). As for the dominant factor in internal function this is the head of the company.

Because the chairman of company is a responsible person for every decision making and internal policy determination company, internal functions make it possible to manage environmental conservation costs effective and efficient and in accordance with decision making. In this function is expected environmental accounting can be a business management tool when dealing with units business. (2) External functions are functions related to financial reporting aspects. In this function an important factor that needs attention by the company is disclosure of results from environmental conservation in the form of accounting data. Information disclosed is the result measured quantitatively from environmental conservation activities. Included in it is information about the economic resources of a company.

According to the Law of the Republic of Indonesia No.23 of 1997 concerning management the environment, the environment is a unitary space with all objects, power, circumstances, and living things including humans and their behavior, which influence continuity of life and well-being of humans and other living things. Environmental accounting is considered because it will be a concern for holders shares by reducing the costs associated with the environment so that It is hoped that reducing environmental costs will create quality a better environment. In addition, the purpose of environmental accounting is also to bridge company interests with overall stakeholders. That is for know the company's activities in dealing with environmental pollution and obligations company over the matter through the company's financial statements. Apart from that, the thing also aims to meet the demands of the law concerning obligations environmental (environmental liabilities) (Hasyim, 2011). Environmental costs are costs incurred by the company related to environmental damage caused and protective 
measures undertaken. Cost the environment includes both internal costs (related to reducing the production process to reduce environmental impacts) as well as external related improvements damage due to waste generated (Susenohaji, 2002).

\section{Legal Basis of Environmental Accounting}

In the regulations contained in Law No.32 of 2009 concerning The Environmental Protection and Management shows several conditions which relating to the implementation of environmental accounting, namely as follows:

1. Everyone is obliged to maintain the preservation of environmental functions and prevent them and tackle pollution and destruction (Article 6 paragraph 1)

2. Everyone who runs a business and/ or activity is obliged to give true and accurate information regarding environmental management (Article 16 paragraph 2)

3. Each party responsible for a business and/ or activity must carry out waste management business results and / or activities (Article 6 paragraph 1)

4. Every party in charge of a business and/ or activity is required to carry out material management dangerous and poisoned (Article 17 paragraph 1)

5. Whoever carries out the law intentionally commits an act that results environmental pollution and / or destruction is threatened with the most imprisonment ten years and a maximum fine of $R p 500,000,000$ (Article 41 paragraph 1)

6. Whoever due to his negligence does the resulting act environmental pollution and/ or damage, threatened with the most imprisonment three years and a maximum fine of Rp100,000.00 (Article 42 paragraph 1)

According to the study of Idris (2012) when it meets the provisions of the law The company that produces waste chooses to process waste to meet it environmental quality standards will certainly require funds to build a Unit of Pengelolaan Limbah (UPL) and finance its operations. That is, for this UPL operation costs are required known as external costs or environmental costs. When viewed from the cost relationship with the resulting product, these costs cannot be classified as both either direct production costs and indirect production costs. While this environmental costs arises, as a result of the production activities carried out by the company to produce a certain product. But when viewed from the company side, environmental costs are external costs, while viewed from the community side these environmental costs are costs internal.

\section{RESEARCH METHODS}

The type of this study is qualitative with interpretive and constructive paradigms approach. In addition, interpretive approaches allow researchers to be involved subjective with study participants. The approaches focus on the subjective nature of social world and try to understand it. Researchers want to explain and describe various situations and the conditions that exist in the object of research are based on reality. In this case researchers want to describe and explain the role and implementation of green accounting in an effort to prevent environmental pollution to support the sustainability of a business company. 
Efektor, Vol. 7. No.1 Tahun 2020, Pages 59-72

Andi Arjuni K., Alimuddin, Hamid Habbe, Mediaty, Andi Maulana K

\section{DISCUSSION}

\section{Review of the Implementation of Green Accounting}

'Green accounting' is a popular term for environmental and natural resource accounting, which is combining environmental assets and source functions and sinking them into national accounts and company ( see Bartelmus, 2008). The United Nations first published a handbook on The system for integrated Environmental and Economic Accounting (SEEA) was integrated in 1993. The SEEA introduces environmental and natural economic assets and the 'environmental costs' of degradation their depletion into the National Balance System (SNA) (UN, 1993). According to Bartelmus's review, the green accounting case study has applied partial market appraisal great for depletion of natural resources. Bartelmus sees the special power of green accounting as measurement of environmental costs caused by household and corporate economic agents. According to him: "The famous polluter / user pay principle is holding agents accountable who are responsible for their environmental impacts 'and' can assess economic and ecological efficiency from different environmental protection measures by government and non- government".

Some of the goals of green accounting are:

1. Assess environmental costs and benefits for a problem

2. To separate and classify various environmental costs

3. To link physical resources with environmental accounts in monetary terms

The company does not account for losses due to damage arising from withdrawals its social ecological resources and impacts. This shows that the company only recognizes load or measure performance (in the form of profit) in the process of carrying out its activities. Even though, it is necessary to increase perception about how an object is attached to the environment natural and social, where raw materials are obtained from, how an object is produced in a way en masse, how its use affects the natural environment and the communities that use it (Capra, 2002a). Ignoring environmental problems and social aspects is clearly a problem for corporate survival. This is caused, survival is closely related to legitimacy social existence of a company in a particular community (Said, 2020). Green accounting at individual or group level or organization, interpreted in a very narrow sense reduce the nature and the potential of human beings who actually have the ability to act within broader dimensions. Raar (2004) for example, emphasizes the importance of social responsibility and environment. Inclusion of the environment and social values in company policy and as an indicator the key to performance, according to him, can enhance reputation and create prosperity for people investors and the company itself.

In other, to achieve its short-term goals, management will try to use them certain techniques and procedures (see Watts, 1977; Watts and Zimmerman, 1978; Healy, 1985) and will to exploit resources to the maximum (see Gorz, 2003). One resource the main are the most exploited by companies in an effort to achieve long-term goals in short is a natural resource. But ironically, nature also gets attention or the smallest contribution. With the higher level of human consumption, then more and more also the resources needed to meet 
their needs. As a result, more and more anyway waste formed during the process of extracting these natural resources (see Soemarwoto, 2004).

Social environmental problems at least support by the emergence of capitalist. This doctrine encourages companies to always look for ways to produce efficiently. Environmental problems caused by company activities are very complex. So it's not It is surprising to say that companies always cause damage (Lina, 2010). Attention and concerns about social and environmental problems were also revealed in Buhr's research (1988); Burritt and Welch (1997); Hemmer (1998); Ljungdahl (2004); Peursem and Lawrence (1995); Raar (2004); Ten (2004); Tilt (2004); Tischler et.al (2002); and Viller and Staden (2004). Although these researchers emphasize different emphases, but basically show their concern on social or environmental aspects as one dimension that needs attentions' company.

As for Solihin (Idris, 2012) stated that the implementation of CSR in Indonesia especially related to CSR for discretionary responsibility categories, can be seen from two different perspectives. First, CSR implementation is the voluntary business practice of the initiative company and is not an activity required by the company in accordance with the law and applicable regulation. Second, the implementation of CSR is in accordance with lawsuits (mandatory). If seen from the application of CSR in Indonesia, it can be said that companies have implemented CSR programs and making a report cannot be said to be a company that has applied accounting environment. This is because the company's operations have not included environmental conservation efforts as an inseparable part (Idris, 2012).

Like other countries, Indonesia also faces a serious ecological or environmental crisis and scary. The crisis has caused various ecological and social disasters very detrimental and threatens human survival. Environmental damage which is caused by human activities as environmental people who do not pay attention to environmental sustainability in utilizing the environment it is very important to foster environmental awareness (Meliyana et al, 2013). Another opinion by Daniel Chiras which states that basic of environmental awareness is environmental ethics. Environmental ethics that valid until now is based on a value system that places human beings not part of nature, but humans as conquerors and regulators of nature. Global warming as an ecological disaster too caused by the excessive exploitation of nature without any rules and considerations mature (Mukhtar, 2010). Climate change and global warming and environmental degradation have causing many natural disasters, social disasters and serious economic disasters.

In this global warming era, the environment becomes a crucial problem. Implementation of green accounting on financial statements of companies needs special attention. The presence of green accounting is one form and awareness of the importance of applying concern for the environment considering the environment has a major contribution to sustainability life is not only for companies but for people in general. As it is known that the main factor caused of global warming is due to increased levels of $\mathrm{CO}_{2}$. Increase levels of $\mathrm{CO}_{2}$ caused by increasing levels of $\mathrm{CO}_{2}$ emissions and reducing the absorbance of $\mathrm{CO}_{2}$ where its functions for filter carbon dioxide into oxygen. The main sectors produced $\mathrm{CO}_{2}$ such as generation energy, oil and industrial transportation. Then technically global warming can be overcome by reducing $\mathrm{CO}_{2}$ emission and increasing $\mathrm{CO}_{2}$ absorbance, for 
example by saving materials fuel, replacement of fossil-based fuels with new/ renewable energy sources such as vehicles electricity, capture $\mathrm{CO}_{2}$. in industrial exhaust emissions by multiplying trees in a house urban area. The high carbon dioxide in an area will affect the conditions the air around it.

Empirical facts showed that after the Law was passed by the House of Representatives in July 2007, many companies began to care and implement mandatory CSER and carried out responsibilities voluntary corporate social (CSR). Many public and private companies began to commit to implement CSER and CSR on an ongoing basis and report the information in the Report Annual Board of Directors. In addition, in addition to the number of companies implementing CSER and CSR continues increased, the level of disclosure of their information in the Annual Report and the Sustainability Report also increased. CSER and CSR have even been recognized as the core needs of the corporation in relationships with stakeholders and strategic investments for companies that grow in business (Lako, 2015b). Many companies also made CSER and CSR an integral part of the system good corporate governance.

To achieve success in the application of environmental accounting, first and foremost thing that needs to be considered by company management is the suitability between evaluations made by the company against the environmental impacts caused. The second step, determine what is target companies by identifying the main factors that have an impact on company environment and compile a plan to reduce environmental impact. The third step, choose the appropriate measurement tool in determining environmental issues. Step fourth, conduct an administrative assessment to set targets in each segment. Step fifth, produce accounting segments to measure each company's divisions. Step sixth, do the testing and the final step is to study performance. On the performance review this is expected to produce an accounting segment that can support management achievements environment in each division.

\section{Green Accounting Concept: Perspective of the Company's Contribution to the Environment}

The concept of Green Accounting or Sustainability Accounting is proposed as a solution to overcome limitations or weaknesses of conventional accounting. A new concept in the accounting world basically based on the values of love for the environment of the universe and our fellow humans in the process accounting. This concept is expected to soon be developed and applied in accounting practices company, state or government entity, and household (Greenham, 2010). Lots of research develops in the area of social accounting disclosure by showing that the company reports that environmental performance is still very limited. Lindrianasari (2007) asserts that is wrong one limitation factor is the lack of legal sanctions in force in the country. Suharto (2004) in Anggriani (2006) some financial management difficulties to report obligations environment, namely requests for disclosure of environmental information in financial reporting have not explicitly, costs and benefits in order to present environmental information in the report finance is felt to be out of balance by the company, introduction of conditional obligations and difficulties in identifying environmental costs. Environmental accounting has difficulty in measuring the value of costs and benefits of externalities arising from industrial processes. It is not easy to measure the losses that people receive at around and the ecological environment caused by air pollution, liquid waste, ammonia tube leakage, nuclear tube leakage or other externalities. Reporting both social performance and 
environmental performance not found in conventional financial statements, which are in conventional financial statements only found only economic performance reports (Idris, 2012). Likewise, what is happening in Indonesia is still considered a complicated concept due to a lack of comprehensive information for stakeholders it is feared that the implementation effect and additional costs will be recognized as expenses that must not be spent in a conventional accounting perspective (Nurhayati, Brown, and Tower, 2006 in Arisandi and Frisko, 2011).

This is consistent with what expressed by Gray et.al (1993) in Burrit and Welch (1997) that disclosure of the costs of externalities will affect decision making and influences stakeholder considerations because market reactions have shown results differ on company activities that do (or do not) social and environmental interests, so that the implementation of environmental accountability will be successful if it supported by law. Gray et.al finally concluded that the mechanism for voluntary disclosure was not appropriate. The evidence from Deegan and Rankin (1996) stated that environmental accounting reporting is biased because companies are frequent not reporting bad news. Therefore, some circles then demanded that the principle, the conceptual framework and accounting standards and regulations that underlie accounting practices so far this needs to be reformed towards being more environmentally friendly. Just as stated by Astuti (2012) that environmental accounting disclosures in developing countries are still very lacking. Green Accounting is the first step which is a solution to the existing environmental problems by evaluating activities environment from the perspective of costs (environmental cost) and benefits (economic benefits) as well produce environmental protection effects (environmental protection). However, this has not yet been achieved said as a concrete solution, environmental accounting can only be a way for certain elements to legalize the company's activities, albeit in various ways the consequences.

\section{CONCLUSION}

Green Accounting was born due to environmental disclosure issues that must be faced where the components that focus on the transaction is not the accounting process relating to activities that will affect the environment. Environmental accounting is a term related to the inclusion of environmental costs into the practice of accounting companies or government institutions. Environmental cost is the impact arising from the financial and non-financial side which must be borne as a result of activities that affect the quality of the environment. With the existence of green accounting the company will be very supportive in the evaluation process such as environmental activities primarily analysis of waste problems. Through the publication of reporting environmental costs will certainly help the stakeholders to evaluate environmental conservation and improve the efficiency of environmental management to support business continuity in the future now and in the future. But unfortunately, in its application, often some companies do not report bad news encountered, so reporting regarding environmental costs is not effective. As explained in Greenham's framework, that the green methodology accounting is devoted to answering three things, namely 1) Who, 2) When, and 3) What. Whose actions are taken into account, then what impact is there on the actions then, how is the measurement, then when will the action be carried out is in the past past, present, or future. That is what we must examine in green accounting. It also can try to describe the key to green accounting in a way look back at the definition and purpose of green accounting itself. So, the results are obtained 
in line with what is expected to be environmentally friendly, not just in the field accounting but in preserving the environment. For further research on the implementation of green accounting, it would be better if given a comparison with other countries. In addition, the steps offered also need to be tested statistically or objectively, whether the steps have been implemented in the company or not in order to produce more accurate data.

\section{Acknowledgment}

We would like to grateful because we managed to complete our paper. This paper cannot be completed without co-operation and suggestions from our group member, $2^{\text {nd }}$ author, $3^{\text {rd }}$ author, $4^{\text {th }}$ author, and $5^{\text {th }}$ author. Last but not least, we also sincerely thank to editorial team of Jurnal Efektor, reviewers and readers for the suggestions and support and willingness to spend some time with us to review our paper.

\section{REFERENCES}

Abdullah, Wahyuddin. 2015. "Pengaruh Tekanan Stakeholders dan Tanggung jawab Sosial terhadap Penerapan Akuntansi Lingkungan di Kawasan Industri Makassar". Assets. Vol. 5, No. 1, Hal. 105114.

Aniela, Yoshi. 2012. "Peran Akuntansi Lingkungan Dalam Meningkatkan Kinerja Lingkungan dan Kinerja Keuangan Perusahaan”. Berkala IImiah Mahasiswa Akuntansi Vol.1, No.1, 137-149

Anggriani, R. R. 2006. "Pengungkapan Informasi Sosial dan Faktor-Faktor yang Mempengaruhi Pengungkapan Informasi Sosial dalam Laporan Keuangan Tahunan (Studi Empiris pada Perusahaan-Perusahaan yang Terdaftar di Bursa Efek Jakarta)". Simposium Nasional Akuntansi 9, Padang

Arisandi, Desi dan Dianne Frisko. 2011. "Green Rush in Accounting Field of Indonesia From Different Perspectives". Papers.ssrn. Vol. 3, No. 1, Hal. 137- 152.

Astuti, Neni. 2012. "Mengenal Green Accounting". Permana. Vol. 4, No. 1. Hal. 69-75

Bartelmus, P. 2008. Measuring Sustainable Economic Growth and Development' in C.J. Cleveland (ed) Encyclopedia of Earth http://doi.org/10.1016/j.cpa.2009.06.004

Bebbington, J. 2001. "Sustainable Development: A Review of the International Development" Business and Accounting Literature, Accounting Forum, Vol. 25, No. 3, p. 128-157

Buhr, Nola. 1998. "Environmental Performance, Legislation and Annual Report Disclosure: The Case of Acid Rain and Falconbridge". Accounting, Auditing \& Accountability Journal, Vol.11, No.2, p.163190

Burhany, Dian Imanina. 2012. "Akuntansi Lingkungan: Dukungan Akuntansi Kepada Manajemen dalam Bisnis yang Semakin Peduli Lingkungan". Proceedings SNEB, p.1-15

Burhany, Dian Imanina. 2014. "Pengaruh Implementasi Akuntansi Lingkungan terhadap Kinerja Lingkungan dan Pengungkapan Informasi Lingkungan. Proceedings SNEB, p.1-8 
Burrit, R.L and S.Welch. 1997. "Accountability for Environmental Performance of the Australian Commonweatlh Public Sector". Accounting, Auditing \& Accountability Journal, Vol.10, No.4: 532561

Capra, Frijof. 2002a. "Jaring-jaring Kehidupan: Visi Baru Epistemologi dan Kehidupan". Terjemahan (Pasaribu). Fajar Pustaka Baru: Yogyakarta

Cooper, C. 1992. "The Non-and Nom of Accounting for (m)other Nature". Accounting, Auditing \& Accountability Journal Vol. 5, No. 3, p. 16-39

Deegan, C. And M, Rankin. 1996. "Do Australian companies report environmental news objectively?" Accounting, Auditing and Accountability Journal. Vol. 9, No. 2, Hal. 50-67.

Dj, Mukhtar. 2010. "Kerusakan Lingkungan Perspektif Al-Quran”. Jakarta

Dowling, J. dan J. Pfeffer. 1975. "Organizational Legitimacy: Social Values and Organizational Behaviour". Pacific Sociology Review, Vol. 18, No. 1: 122-136

Gorz, Andre. 2003. "Ekologi dan Krisis Kapitalisme". Cetakan Kedua. Insist Press: Yogyakarta

Greenham, Tony. 2010. "Green Accounting: A Conceptual Framework." International Journal of Green Economics 4(4):333-45.

Hadjoh, Rinny Amelia dan I Made Sukartha, 2013, "Pengaruh Ukuran Perusahaan Kinerja Keuangan dan Eksposur Media pada Pengungkapan Informasi Lingkungan". E-Journal Akuntansi Universitas Udayana, Vol. 4, No. 1, p. 1-17

Hasyim. 2011. "Akuntansi Lingkungan: Apakah Sebuah Pilihan atau Kewajiban”. Jurnal.

Healy, P. 1985. "The Impact of Bonus Scheme on the Selecion of Accounting Principles". Journal of Accounting and Economic 7 (1985) 85-107. North Holland

Hemmer, Thomas. 1988. "Performance Measurement System Incentive, and the Optional Allocation of Resonsibilities". Journal of Accounting and Economics, 25:321-347

Idris. 2012. "Akuntansi Lingkungan Sebagai Instrumen Pengungkapan Tanggung Jawab Perusahaan Terhadap Lingkungan di Era Green Market". Jurnal economic. Vol. 2, No. 2, Hal. 1-10

Ikbal, Muhammad. 2012. "Akuntansi Lingkungan Sebagai Instrumen Pengungkapan Tanggung Jawab Perusahaan Terhadap Lingkungan di Era Green Market”. Jurnal Economic, Vol. 2, No. 2, p.1-10

Ikhsan Arfan. 2008. "Akuntansi Lingkungan dan Pengungkapannya”. Graha IImu: Yogyakarta.

Kerap, A.Sonny. 2006. "Etika Lingkungan”. Kompas:Jakarta.

Lako, A. 2015b. "Berkah CSR Bukan Fiksi". La Tofi Publishing Enterprises. Edisi Pertama

Lako, A. 2011. "Dekonstruksi CSR dan Reformasi Paradigma Bisnis dan Akuntansi". Penerbit Erlangga: Jakarta.

Lindrianasari. 2007. "Hubungan antara Kinerja Lingkungan dan Kualitas Pengungkapan Lingkungan dengan Kinerja Ekonomi Perusahaan di indonesia". JAAI, Vol.11, No. 2

Ljungdahl, Fredrik. 2004. "Factors Influencing Environmental and Social Disclosure". The Fourth Asia Pasific Interdiciplinary Research in Accounting (Apira) 2004. Conference. Singapore 
Lodhia, Sumit K. 2008. "Environmental Accounting in Fiji: An Extended Case Study of the Fiji Sugar Corporation". SSRN

Meliyana, dkk. 2013. "Gerakan Lingkungan Hidup Dalam Menumbuhkan Kesadaran Lingkungan Masyarakat Belitung". Jurnal Volume 1, Nomor 2, ISSN: 2337-5205

Peursem., K.A Van, M.J Pratt dan S.R Lawrence. 1995. "Health Management Performance: A Review of Measures and Indicators". Accounting, Auditing \& Accountability Journal, Vol 8, No.5: 34-70

Raar, Jean. 2004. "Environmental and Social Responsibility: A Normative Financial Reporting Concept". The Fourth Asia Pasific Interdiciplinary Research in Accounting (Apira) 2004. Conference. Singapore

Riduwan, Akhmad dan Andayani. 2011. "Tanggung Jawab Lingkungan dan Peran Informasi Lingkungan dalam Pengambilan Keputusan Manajemen: Studi Kualitatif”. Simposium Nasional Akuntansi 9 , Aceh

Said, Darwis. 2020. "Kearifan Lingkungaan dalam Praktik Akuntansi”. Cetakan Pertama. Tohar Media: Makassar

Soemarwoto, Otto. 2004. "Ekologi, Lingkungan Hidup, dan Pembangunan”. Cetakan ke-10. Djambatan: Jakarta

Ten, E. Eljido. 2004. "Determinations of Environmental Disclosures in Developing Country: An Application of the Stakeholder Theory". The Fourth Asia Pasific Interdiciplinary Research in Accounting (Apira) 2004. Conference". Singapore

Tilt, Carol A. 2004. "A Note on Linking Environmental Activity and Environmental Disclosure". The Fourth Asia Pasific Interdiciplinary Research in Accounting (Apira) 2004. Conference. Singapore

Tischler, Len., J. Biberman, dan R. McKeage. 2002. "Linking Emotional Intelligence, Spirituality and Workplace Performance: Definitions, Models, and Ideas for Research". Journal of Managerial Psychology, Vol. 17, No. 3, 203-218

United Nations, UN. 1993. Handbook of National Accounting System of Integrated Environmental and Economic Accounting - System of Integrated Environmental and Economic Accounting, p.198

Viller Ch. D and Ch. Staden. 2004. "Trend in Environmental Reporting: Evidence from Africa". The Fourth Asia Pasific Interdiciplinary Research in Accounting (Apira) 2004. Conference". Singapore

Watts, Ross. 1977. "Corporate Financial Statements, A Product of the Market and Polilical Processeses". Australian Journal of Management, April: 53-75

Watts, Ross and Jerold Zimmerman. 1978. "Towards a Positive Accounting of the Determinant of Accounting of the Determinant of Accounting Standards". Accounting Review, Jan: 112-134 